\title{
PERBEDAAN PENGETAHUAN GIZI, BODY IMAGE, ASUPAN ENERGI DAN STATUS GIZI PADA MAHASISWI GIZI DAN NON GIZI UNIVERSITAS DIPONEGORO
}

\author{
Salsa Bening, Ani Margawati*) \\ Program Studi Ilmu Gizi Fakultas Kedokteran Universitas Diponegoro \\ Jl.Dr.Sutomo No.18, Semarang, Telp (024) 8453708, Email : gizifk@undip.ac.id
}

\begin{abstract}
Background: Amount of $8.7 \%$ population aged > 18 years have malnutrition. This shows that the problem of malnutrition in Indonesia is still a major health problem. In the period from adolescence to adulthood, a person requires a balanced nutrition. However, because of the desire of having an ideal body causing restriction period is prone to food intake. Good knowledge about nutrition can affect food intake person that will have an impact on nutritional status.

Purpose: To determine the differences in nutrition knowledge, body image, energy intake, and nutritional status in college student nutrition and non nutrition Diponegoro University.

Method: The cross-sectional study using 80 female students in Faculty of Medicine and Faculty of Law, University of Diponegoro. The data collected were identity data form, and measured using questionnaire include nutrition knowledge, body image, energy intake obtained from three days food recall form, and nutritional status that obtained from weight and height. Data analysis using the Mann Whitney test of different between college student of nutrition groups and non nutrition.

Result: A total of 80 female students with 19-21 years old, consisting of 40 female students of nutrition and 40 non nutrition. The mean scores of nutrition knowledge on college students of nutrition is $91.375 \pm 7.069$, while non nutrition is $66.625 \pm 14.909$. The mean scores of body image on college students of nutrition is $82.200 \pm 23$. 848, while the non nutrition is $86.975 \pm 32.506 .65 \%$ of the whole subjects had not eating behaviors well and $67.5 \%$ of all subjects had a good nutritional status. Different test: nutrition knowledge $(p=0.00)$, body image $(p=0.155)$, energy intake $(p=0.162)$, and nutritional status $(p=0.34)$.

Conclusion: There were significantly different between the groups in the subject of nutrition knowledge of nutrition and non-nutrition college students. While there were no significantly different in body image, energy intake and nutritional status.
\end{abstract}

Keywords: nutrition knowledge; body image; energy intake; nutritional status

\section{ABSTRAK}

Latar Belakang: Sebesar $8.7 \%$ penduduk usia >18 tahun mengalami gizi kurang. Hal ini menunjukkan bahwa permasalahan gizi di Indonesia masih menjadi masalah kesehatan utama. Pada periode remaja hingga dewasa, seseorang memerlukan asupan gizi yang seimbang. Akan tetapi karena adanya keinginan memiliki tubuh yang ideal menyebabkan periode tersebut rentan terhadap pembatasan asupan makan. Pengetahuan yang baik mengenai gizi dapat mempengaruhi asupan makan seseorangan sehingga akan berdampak pula terhadap status gizinya.

Tujuan: Mengetahui perbedaan pengetahuan gizi, body image, asupan energi, dan status gizi pada mahasiswi gizi dan non gizi Universitas Diponegoro.

Metode: Jenis penelitian cross sectional yang dilakukan pada 80 mahasiswi semester 4 di Fakultas Kedokteran dan Fakultas Hukum Universitas Diponegoro. Data yang diambil adalah data mengenai identitas diri, dan kuesioner yang meliputi pengetahuan gizi, body image, asupan energi yang diperoleh dari recall $3 x 24$ jam, serta status gizi yg diperoleh dari berat badan dan tinggi badan. Analisa data menggunakan uji beda Mann Whitney antara kelompok mahasiswi gizi dan mahasiswi non gizi.

Hasil: Sebanyak 80 subjek mahasiswi usia 19-21 tahun, terdiri dari 40 mahasiswi gizi dan 40 mahasiswi non gizi. Rerata skor pengetahuan gizi pada mahasiswi gizi sebesar $91.375 \pm 7.069$, sedangkan non gizi sebesar $66.625 \pm$ 14.909. Rerata skor body image pada mahasiswi gizi sebesar $82.200 \pm 23.848$, sedangkan non gizi sebesar $86.975 \pm$ 32.506. Sebesar 60\% dari keseluruhan subjek belum memiliki asupan energi cukup dan sebesar 67.5\% dari keseluruhan subjek memiliki status gizi yang baik. Uji beda: pengetahuan gizi $(p=0.00)$, body image $(p=0.155)$, asupan energi $(p=0.162)$, dan status gizi $(p=0.34)$.

Simpulan: Terdapat perbedaan pengetahuan gizi yang bermakna antara kelompok mahasiswi gizi dan non gizi. Sedangkan tidak terdapat perbedaan yang bermakna pada body image, asupan energi dan status gizi.

Kata kunci: pengetahuan gizi; body image; asupan energi; status gizi

\section{PENDAHULUAN}

Permasalahan gizi merupakan salah satu masalah kesehatan utama di Indonesia. Masalah gizi kurang maupun gizi lebih merupakan masalah kesehatan yang sering dijumpai pada usia dewasa. ${ }^{1}$ Status gizi adalah salah satu prediktor kualitas

\footnotetext{
${ }^{*}$ Penulis Penanggungjawab
} 
sumberdaya manusia. ${ }^{2}$ Hasil Riset Kesehatan Dasar tahun 2013 oleh Departemen Kesehatan Republik Indonesia mengenai status gizi menurut IMT penduduk usia $>18$ tahun menunjukkan bahwa sebesar $8,7 \%$ mengalami gizi kurang, $13,5 \%$ mengalami gizi lebih, dan $15,4 \%$ mengalami obesitas. Jawa Tengah merupakan salah satu propinsi yang memiliki angka prevalensi gizi kurang lebih tinggi dari prevalensi nasional untuk penduduk usia $>18$ tahun, yakni sebesar $10 \%{ }^{3}$

Status gizi dipengaruhi oleh beberapa faktor, antara lain adalah asupan energi, pengetahuan gizi dan body image. Menurut Achmad Djaeni, permasalahan gizi terjadi karena perilaku makan seseorang yang tidak tepat, yaitu adanya ketidakseimbangan antara asupan energi dengan angka kecukupannya sehingga akan berdampak pada status gizi. ${ }^{4}$ Sedangkan pada penelitian Merinta Sada terhadap mahasiswa politeknik kesehatan di Jayapura menyebutkan bahwa terdapat hubungan antara pengetahuan gizi dan body image dengan status gizi menurut IMT. ${ }^{5}$

Pengetahuan gizi adalah pemahaman seseorang mengenai gizi seimbang yang diperlukan oleh tubuh sehingga dapat menjaga kesehatan secara optimal. ${ }^{6}$ Seseorang yang memiliki pengetahuan gizi baik diharapkan memiliki asupan zat gizi yang baik pula. Namun, penelitian Pramadavita Andini pada tahun 2010 terhadap mahasiswa Prodi Ilmu Gizi Universitas Diponegoro mengenai hubungan pengetahuan dengan asupan zat gizi makro dan mikro menunjukkan bahwa 90,8\% tingkat pengetahuan gizi responden baik, namun tingkat asupan energi, karbohidrat, protein, lemak, besi dan seng tergolong defisiensi. ${ }^{7} \mathrm{Hal}$ ini menunjukkan bahwa meskipun mahasiswa gizi memiliki tingkat pengetahuan gizi yang baik, belum dapat menjamin bahwa asupan gizinya juga akan baik. $^{7,8}$

Body image merupakan suatu persepsi seseorang mengenai bentuk tubuhnya. ${ }^{9}$ Setiap orang memiliki penilaian terhadap bentuk tubuhnya masing-masing. Keinginan memiliki tubuh yang langsing dan ideal merupakan suatu hal yang diidamkan oleh sebagian besar kaum wanita. Penelitian Nidya Magdalena terhadap remaja putri di Malang menyebutkan bahwa body image mempengaruhi status gizi mereka. ${ }^{10}$ Penelitian lain oleh Kusumajaya menyebutkan bahwa sebesar $41,1 \%$ responden merasa memiliki berat badan yang berlebih atau beranggapan bahwa dirinya gemuk padahal sebenarnya kurus. Kecenderungan ini lebih banyak terjadi pada remaja putri yakni sebesar 45,2\%. ${ }^{11}$ Penelitian mengenai citra tubuh dan konsep tubuh ideal terhadap mahasiswi FISIP
Universitas Airlangga Surabaya masih bersifat negatif, artinya tidak ada mahasiswi yang menyatakan sudah puas dengan bentuk dan ukuran tubuhnya. ${ }^{12}$ Berbeda bagi ahli gizi, body image merupakan hal penting yang perlu diperhatikan karena mereka akan berperan sebagai konselor sehingga akan mempengaruhi kepercayaan dari klien dan mempengaruhi keberhasilan dalam konseling yang diberikan. ${ }^{13}$

Pengetahuan gizi dan body image merupakan faktor yang dapat mempengaruhi perilaku makan seseorang. ${ }^{14}$ Perilaku makan berkaitan dengan konsumsi makanan yang mencakup pemilihan jenis makanan, kebiasaan makan, pola makan, frekuensi makan dan asupan energi. Masalah yang terkait dengan perilaku makan yang utama adalah mengenai kurangnya asupan zat gizi terutama asupan energi dalam sehari. Hal ini terjadi disebabkan karena seringnya meninggalkan waktu sarapan karena padatnya aktivitas, terlalu membatasi makanan, tidak terlalu peduli terhadap pemilihan makanan yang dikonsumsi, jarang mengkonsumsi sayur dan buah, mengikuti trend makanan cepat saji dan sebagainya. ${ }^{15}$

Mahasiswi merupakan kelompok usia produktif yang termasuk dalam periode dewasa awal. Dalam perkembangannya mereka memerlukan asupan gizi yang seimbang supaya terhindar dari berbagai penyakit degeneratif yang berdampak pada penurunan produktivitas. ${ }^{16}$ Namun periode ini rentan terhadap pembatasan asupan makan karena adanya keinginan memiliki bentuk tubuh yang ideal, adanya perubahan gaya hidup, maupun pengaruh lingkungan dan teman sebaya. ${ }^{17}$ Mahasiswi Program Studi Ilmu Gizi dianggap memiliki pengetahuan yang baik mengenai gizi karena menempuh pendidikan berbasis gizi. Mereka dianggap memiliki pengetahuan gizi yang baik dibandingkan dengan jurusan selain gizi.

Berdasarkan uraian masalah tersebut, peneliti tertarik melakukan penelitian untuk mengetahui perbedaan pengetahuan gizi, body image, asupan energi dan status gizi pada mahasiswi gizi dan non gizi.

\section{METODE}

Sampel yang dipilih adalah mahasiswi Program Studi Ilmu Gizi Fakultas Kedokteran dan mahasiswi Fakultas Hukum Universitas Diponegoro. Dipilih mahasiswi Fakultas Hukum karena mereka diasumsikan sangat memperhatikan penampilan saat kuliah. Sebanyak 80 subjek penelitian yang terdiri dari 40 mahasiswi gizi dan 40 mahasiswi non gizi. Subjek penelitian diambil dengan cara simple random sampling, yaitu dengan 
menggunakan kuesioner penyaringan, kemudian dipilih sesuai dengan kriteria penelitian. Kriteria inklusinya antara lain adalah mahasiswi program studi Ilmu Gizi Fakultas Kedokteran dan mahasiswi Fakultas Hukum semester 4 yang berusia 19-24 tahun, tidak sedang menjalani program diet tertentu, tidak menderita penyakit infeksi terkait gizi dalam 2 minggu terakhir, tidak sedang menggunakan obatobatan tertentu yang dapat mempengaruhi asupan makanan dan bersedia menjadi sampel serta bersedia mengisi informed consent. Pengambilan data penelitian ini dilakukan pada bulan Juni 2014.

Variabel yang diteliti meliputi pengetahuan gizi, body image, asupan energi dan status gizi. Untuk variabel pengetahuan gizi, body image dan asupan energi diukur menggunakan kuesioner. Pengetahuan gizi merupakan pemahaman mahasiswi tentang ilmu gizi, meliputi sumbersumber zat gizi dalam makanan, serta fungsi dan manfaatnya bagi tubuh. Pengambilan data menggunakan kuesioner pengetahuan, dengan bentuk pertanyaan multiple choice berjumlah 20 soal, skor 1 untuk jawaban benar dan skor 0 untuk jawaban salah, dikategorikan menjadi pengetahuan gizi kurang ( $<60 \%$ jawaban benar), pengetahuan gizi sedang; (60-80\% jawaban benar), dan pengetahuan gizi tinggi ( $>80 \%$ jawaban benar). ${ }^{18}$ Body image merupakan persepsi mahasiswi mengenai penampilan bentuk tubuhnya. Diukur dengan menggunakan kuesioner Body Shape Questionnaire (BSQ) yang berisi 34 pertanyaan dengan rentang skala 1 (tidak pernah) sampai 6 (selalu), dengan total skor 34 - 204. ${ }^{19}$ Dikategorikan menjadi persepsi tubuh positif; apabila skor $\leq 110$ dan persepsi tubuh negatif; apabila skor $>110 .{ }^{20}$ Asupan energi merupakan total asupan makanan dan minuman mahasiswi selama sehari. Diperoleh menggunakan recall 3x24 jam. Dikategorikan menjadi kurang (apabila asupan energi $<80 \%$ dari AKG), cukup (apabila asupan energi 80 - 100\% dari AKG) dan lebih (apabila asupan energi $>100 \%$ dari AKG ). ${ }^{21}$ Status gizi merupakan keadaan kesehatan fisik yang merupakan ekspresi dari konsumsi, penyerapan dan penggunaan zat gizi. Pengukuran berat badan dan tinggi badan dilakukan menggunakan timbangan injak digital dan microtoise. Status gizi akan dinilai dengan indikator antropometri IMT menggunakan rumus IMT $=\mathrm{BB}$ $(\mathrm{kg}) / \mathrm{TB}^{2}(\mathrm{~m})$. Dikelompokkan menjadi gizi kurang (apabila IMT < 18,5), gizi baik (apabila IMT 18,5 22,9) dan gizi lebih (apabila IMT > 23).

Pengolahan dan analisis data dilakukan menggunakan komputer dengan analisis univariat dan bivariat. Analisis univariat dilakukan dengan menyajikan data tabel distribusi. Analisis dilakukan terhadap data pengetahuan gizi, body image, asupan energi dan status gizi. Data kemudian diuji normalitasnya dengan Kolmogorov-Smirnov. Kemudian analisis bivariat dilakukan untuk melihat beda antara masing-masing variabel meliputi pengetahuan gizi, body image, asupan energi dan status gizi mahasiswa gizi dan non gizi menggunakan uji Mann Whitney.

\section{HASIL}

Karakteristik subjek yang terdiri dari usia, tempat tinggal besarnya uang saku per bulan, pengetahuan gizi, body image, asupan energi dan status gizi digunakan untuk mendeskripsikan subjek penelitian secara jelas. Dari 80 subjek penelitian yang berasal dari mahasiswi Fakultas Kedokteran dan Fakultas Hukum Universitas Diponegoro, karakteristik subjek penelitian disajikan dalam Tabel 1.

Tabel 1. Karakteristik Subjek

\begin{tabular}{lccc}
\hline Karakteristik Subjek & $\begin{array}{c}\text { Mahasiswi Gizi } \\
(\mathrm{n}=40)\end{array}$ & $\begin{array}{c}\text { Mahasiswi Hukum } \\
(\mathrm{n}=40)\end{array}$ & $\%$ \\
\hline Usia & 6 & 10 & 20 \\
19 tahun & 29 & 27 & 70 \\
20 tahun & 5 & 3 & 10 \\
$\quad 21$ tahun & & & 76.25 \\
Tempat Tinggal & 30 & 31 & 23.75 \\
$\quad$ Kos & 10 & 9 & 67.5 \\
$\quad$ Rumah & 30 & 24 & 32.5 \\
Uang Saku & 10 & 16 & 52.5 \\
$\quad \leq 1.000 .000$ & & & 36.25 \\
$\quad>1.000 .000$ & 36 & 6 & 25 \\
$\quad$ Pengetahuan Gizi & 4 & & \\
$\quad$ Tinggi $(>80)$ & & & \\
$\quad$ Sedang $(60-80)$ & & & \\
\hline
\end{tabular}




\begin{tabular}{lccc}
\hline Kurang $(<60)$ & - & 9 & 11.25 \\
$\begin{array}{c}\text { Body image } \\
\text { Persepsi tubuh } \\
\text { positif }(\leq 110)\end{array}$ & & & \\
Persepsi tubuh & 35 & 30 & 81.25 \\
$\quad$ negatif $(>110)$ & 5 & 10 & 18.75 \\
Asupan energi & & & \\
Kurang & 21 & 11 & 60 \\
Cukup & 17 & 2 & 55 \\
Lebih & 2 & 8 & 16.25 \\
Status Gizi & 5 & 26 & 67.5 \\
Kurang $(<18.5)$ & 28 & 6 & 16.25 \\
Baik $(18.5-22.9)$ & 7 & & \\
Lebih $(>22.9)$ & & &
\end{tabular}

Sebaran usia dalam penelitian ini berkisar antara $19-21$ tahun. Rata-rata responden berada pada usia 20 tahun. Sebanyak $72.5 \%$ mahasiswi gizi dan $67.6 \%$ mahasiswi hukum memiliki usia 20 tahun. Sebagian besar responden tinggal di kos. Sebanyak $75 \%$ mahasiswi gizi dan $77.5 \%$ mahasiswi hukum tinggal di kos, sedangkan sebanyak 25\% mahasiswi gizi dan $23.75 \%$ mahasiswi hukum tinggal di rumah.

Rata-rata uang saku mahasiswi hukum sebesar Rp 1.087.500 \pm 438.053 perbulan lebih tinggi dibandingkan dengan rata-rata uang saku mahasiswi gizi sebesar Rp $946.250 \pm 506.798$ perbulan. Uang saku berasal dari orang tua, beasiswa maupun dari sumber lainnya.

Tabel 2. Karakteristik Variabel

\begin{tabular}{lccc}
\hline \multicolumn{1}{c}{ Karakteristik } & Mahasiswi Gizi & Mahasiswi Hukum & Total \\
\hline Skor Pengetahuan Gizi & $91.37 \pm 7.06$ & $66.62 \pm 14.90$ & $79.00 \pm 17.01$ \\
Skor Body Image & $82.2 \pm 23.84$ & $86.97 \pm 32.50$ & $84.58 \pm 28.42$ \\
Asupan Energi & $1766.67 \pm 183.31$ & $1639.56 \pm 239.68$ & $1702.82 \pm 221.36$ \\
IMT & $20.79 \pm 0.38$ & $20.57 \pm 0.45$ & $20.68 \pm 0.29$ \\
\hline
\end{tabular}

Mahasiswi gizi sebagian besar memiliki pengetahuan gizi tinggi yaitu sebesar $90 \%$, sedangkan pada mahasiswi hukum sebagian besar memiliki pengetahuan gizi sedang yaitu sebesar $62.5 \%$. Nilai rata-rata \pm standar deviasi skor pengetahuan gizi pada mahasiswi gizi sebesar $91.375 \pm 7.069$, sedangkan pada mahasiswi hukum sebesar $66.625 \pm 14.909$.

Sebesar $81.25 \%$ dari seluruh responden memiliki persepsi tubuh positif. Mahasiswi gizi memiliki persepsi tubuh positif sebesar $87.5 \%$, sedangkan mahasiswi hukum memiliki persepsi tubuh positif sebesar $75 \%$. Nilai rata-rata \pm standar deviasi skor body image pada mahasiswi gizi sebesar 82.200 \pm 23.848, sedangkan pada mahasiswi hukum sebesar $86.975 \pm 32.506$. Sebesar
$60 \%$ dari seluruh responden memiliki asupan energi kurang. Sebesar $67.5 \%$ mahasiswi hukum dan $52.5 \%$ mahasiswi gizi memiliki asupan energi kurang.

Sebagian besar status gizi mahasiswi $(67.5 \%)$ termasuk dalam kategori status gizi baik. Mahasiswi yang memiliki status gizi baik pada kelompok mahasiswi gizi sebesar $70 \%$ sedangkan pada kelompok mahasiswi hukum sebesar $67.5 \%$. Terdapat 5 mahasiswi gizi dan 8 mahasiswi hukum yang memiliki status gizi kurang, serta terdapat 7 mahasiswi gizi dan 6 mahasiswi hukum yang memiliki status gizi lebih. Nilai rata-rata \pm standar deviasi status gizi mahasiwi gizi sebesar $20.792 \pm$ 2.450 , sedangkan pada mahasiswi hukum sebesar $20.575 \pm 2.899$.

Tabel 3. Analisis Bivariat

\begin{tabular}{rccc}
\hline & Mahasiswi Gizi & Mahasiswi Hukum & $P$ \\
\hline Pengetahuan Gizi & & & \\
Tinggi & $36(90 \%)$ & $6(15 \%)$ & 0.000 \\
Sedang & $4(10 \%)$ & $25(52.5 \%)$ & \\
Kurang & - & $9(22.5 \%)$ & \\
Body Image & & & \\
\hline
\end{tabular}




\begin{tabular}{cccc}
\hline Positif & $35(87.5 \%)$ & $30(75 \%)$ & 0.155 \\
Negatif & $5(12.5 \%)$ & $10(25 \%)$ & \\
Asupan Energi & & & 0.162 \\
Lebih & $2(5 \%)$ & $2(5 \%)$ & \\
Cukup & $17(42.5 \%)$ & $11(27.5 \%)$ & \\
Kurang & $21(52.5 \%)$ & $27(67.5 \%)$ & 0.340 \\
Kurang & $5(12.5 \%)$ & $8(20 \%)$ & \\
Baik & $28(70 \%)$ & $26(65 \%)$ & \\
Lebih & $7(17.5 \%)$ & $6(15 \%)$ & \\
\hline
\end{tabular}

Berdasarkan uji Mann-Whitney diperoleh angka significancy 0.000 , maka dapat dikatakan bahwa ada perbedaan bermakna antara pengetahuan gizi kelompok mahasiswi gizi dan pengetahuan gizi kelompok mahasiswi hukum. Sebagian besar mahasiswi berpengetahuan gizi tinggi, sedangkan sebagian besar mahasiswi hukum perngetahuan gizi sedang.

Tidak terdapat perbedaan yang bermakna terhadap body image ( $p=0.155)$, asupan energi ( $p$ $=0.162)$ dan status gizi $(p=0.340)$ antara kelompok mahasiswi gizi dan mahasiswi hukum. Kedua kelompok sebagian besar memiliki body image positif, asupan energi kurang dan memiliki status gizi baik.

\section{PEMBAHASAN \\ Pengetahuan Gizi}

Pengetahuan gizi merupakan hasil tahu seseorang mengenai segala sesuatu yang berkaitan dengan gizi. Pengetahuan gizi dapat dipengaruhi oleh beberapa hal, salah satunya adalah pendidikan mengenai gizi. ${ }^{14,22}$ Dalam penelitian ini, menggunakan dua kelompok sampel berbeda yaitu mahasiswi gizi dan mahasiswi non gizi. Mahasiswi gizi adalah mahasiswi yang berasal dari ilmu gizi Fakultas Kedokteran Universitas Diponegoro, dimana selama perkuliahan selalu mendapatkan mata kuliah mengenai gizi, sedangkan mahasiswi non gizi adalah mahasiswi yang berasal dari Fakultas Hukum Universitas Diponegoro, dimana selama perkuliahan tidak pernah mendapatkan mata kuliah mengenai gizi. Hasil analisa menyebutkan bahwa mahasiswi gizi sebagian besar memiliki pengetahuan gizi tinggi yaitu sebesar 90\%, sedangkan pada mahasiswi hukum sebagian besar memiliki pengetahuan gizi sedang yaitu sebesar $62.5 \%$. Nilai rata-rata \pm standar deviasi skor pengetahuan gizi pada mahasiswi gizi sebesar $91.375 \pm 7.069$, sedangkan pada mahasiswi hukum sebesar $66.625 \pm 14.909$. Berdasarkan uji beda Mann Whitney didapatkan hasil bahwa terdapat perbedaan yang bermakna antara pengetahuan gizi pada kelompok mahasiswi gizi dan hukum.
Perbedaan pengetahuan gizi pada kedua kelompok sampel dipengaruhi oleh latarbelakang pendidikan sampel. Sebagai mahasiswi gizi tentunya mereka memiliki pengetahuan yang lebih baik mengenai gizi, karena mereka mendapatkan mata kuliah mengenai gizi dan segala sesuatu yang mereka pelajari tidak jauh dari permasalahan gizi. Sedangkan sebagian besar mahasiswi hukum memiliki pengetahuan gizi yang sedang, hal ini dapat terjadi karena sebelumnya mereka pernah mendapatkan informasi dari pendidikan formal di sekolah maupun non formal yang diperoleh dari buku, internet dan berbagai media massa lainnya.

\section{Body Image}

Body image merupakan persepsi seseorang mengenai bentuk dan ukuran tubuhnya sendiri, hal ini dipengaruhi oleh bentuk dan ukuran tubuh aktualnya, perasaannya tentang bentuk tubuhnya serta harapan terhadap bentuk dan ukuran tubuh yang diinginkannya. ${ }^{23,24}$ Remaja putri cenderung lebih tidak puas dengan penampilan tubuhnya dan cenderung melebih-lebihkan ukuran tubuhnya dibandingkan pria. Dalam penelitian disebutkan bahwa body image merupakan salah satu faktor penting yang berkaitan dengan status gizi seseorang. ${ }^{25}$ Sedangkan bagi seorang ahli gizi, body image cukup penting karena mereka akan menemui klien sehingga akan dapat mempengaruhi kepercayaan dari klien dan kesuksesan dalam pemberian konseling. ${ }^{13}$

Sebesar $81.25 \%$ dari seluruh responden memiliki persepsi tubuh positif. Mahasiswi gizi memiliki persepsi tubuh positif sebesar $87.5 \%$, sedangkan mahasiswi hukum memiliki persepsi tubuh positif sebesar $75 \%$. Nilai rata-rata \pm standar deviasi persepsi body image pada mahasiswi gizi sebesar $82.200 \pm 23.848$,sedangkan pada mahasiswi hukum sebesar 86.975 \pm 32.506 . Berdasarkan uji beda Mann Whitney didapatkan hasil bahwa tidak terdapat perbedaan yang bermakna antara persepsi body image pada kelompok mahasiswi gizi dan hukum. $(p=0.155)$

Mahasiswi yang memiliki persepsi tubuh yang positif akan memiliki rasa percaya diri yang 
tinggi. Individu yang memiliki persepsi tubuh positif akan mempunyai perhatian terhadap persoalan kesehatan seperti pemilihan konsumsi makanan yang sehat. Sebaliknya, individu yang memiliki persepsi tubuh negatif dinilai merasakan ketidakpuasan terhadap bentuk tubuh dan berat badan, merasa kurang sehat, dan berpikir bagaimana menjadi ideal yang menyebabkan individu menjadi tidak perhatian terhadap pemilihan konsumsi makanan yang sehat dan membatasi asupan makan. ${ }^{12,26}$

\section{Asupan Energi}

Asupan energi merupakan total asupan makanan maupun minuman selama satu hari. Merupakan respon seseorang terhadap makanan sebagai kebutuhan vital bagi kehidupan. ${ }^{27,28}$ Pada penelitian ini didapatkan hasil bahwa sebesar $60 \%$ dari seluruh responden belum memiliki asupan energi yang cukup. Hal ini ditunjukkan dengan asupan energi sebagian besar subjek tidak sesuai dengan angka kecukupan gizi pada wanita usia 19 29 tahun menurut AKG tahun 2013 adalah sebesar 2250 kkal. Sebesar $67.5 \%$ mahasiswi hukum dan $52.5 \%$ mahasiswi gizi memiliki asupan energi kurang. Berdasarkan uji Mann Whitney disebutkan bahwa tidak ada perbedaan yang bermakna antara asupan energi kelompok mahasiswi gizi dan hukum.

Asupan energi seseorang dapat dipengaruhi oleh berbagai faktor, beberapa diantaranya adalah pengetahuan gizi, body image, status tempat tinggal, lingkungan serta besarnya uang jajan. ${ }^{29,30}$ Meskipun mahasiswi gizi rata-rata memiliki pengetahuan gizi tinggi, namun asupan energinya tidak berbeda dengan mahasiswi hukum yang rata-rata memiliki pengetahuan gizi sedang. Kebiasaan makan seperti meninggalkan sarapan pagi, kurangnya frekuensi makan dalam sehari, kurangnya frekuensi makan sayur dan buah, seringnya konsumsi fast food dan kurangnya asupan energi dalam sehari masih banyak ditemukan dalam kedua kelompok baik mahasiswi gizi maupun hukum.

Menurut Khomsan, pengetahuan tentang gizi akan mempengaruhi komposisi dan konsumsi pangan seseorang, akan tetapi seseorang yang memiliki pengetahuan gizi baik, belum tentu dapat mengubah kebiasaan makannya. ${ }^{18}$ Pada umumnya seseorang dengan pengetahuan gizi akan memiliki asupan yang lebih baik, akan tetapi meskipun memiliki pengetahuan gizi yang baik, mereka tidak sepenuhnya dapat merubah kebiasaan makan menjadi sehat.

Kurangnya dukungan dari lingkungan, sulitnya mendapatkan makanan yang sehat, maupun kendala lainnya merupakan hambatan seseorang tidak dapat merubah kebiasaan makannya menjadi lebih baik. ${ }^{31,32}$ Penyebab lainnya adalah karena sebagian besar mahasiswi hidup sendiri, dimana sebanyak $75 \%$ mahasiswi gizi dan $77.5 \%$ mahasiswi hukum tinggal di kos, sedangkan sebanyak 25\% mahasiswi gizi dan $23.75 \%$ mahasiswi hukum tinggal di rumah. Diasumsikan bahwa seseorang yang tinggal di kos mengupayakan sendiri makanan yang dikonsumsi. Mereka mengalami ketidakmampuan di dalam menyediakan makanan sehari-hari sehingga mereka harus membeli di warung atau rumah makan, maka makanan yang dikonsumsi tidak beragam. Berbeda dengan mereka yang tinggal di rumah, karena diasumsikan bahwa dengan tinggal di rumah asupannya lebih terjaga, lebih sehat, dan dalam variasi maupun ketersediannnya pun juga mencukupi. Selain itu disebabkan karena besarnya uang saku yang beragam dari masing-masing mahasiswi yang diterima setiap bulan mengakibatkan adanya perbedaan dalam hal kemampuan untuk membeli makanan yang akan dikonsumsi setiap harinya, baik dari segi kualitas maupun kuantitas.

\section{Status Gizi}

Status gizi merupakan keadaan seseorang yang diakibatkan oleh konsumsi, penyerapan dan penggunaan zat gizi dari makanan dalam jangka waktu yang lama. Status gizi responden ditentukan dengan Indeks Massa Tubuh (IMT). Berdasarkan uji beda menunjukkan tidak terdapat perbedaan yang bermakna antara status gizi $(\mathrm{p}>0.05)$ pada kedua kelompok mahasiswi gizi dan hukum. Hasilnya menyebutkan bahwa sebagian besar status gizi mahasiswi (67.5\%) termasuk dalam kategori status gizi baik. Mahasiswi yang memiliki status gizi baik pada kelompok gizi sebesar 70\% sedangkan pada kelompok hukum sebesar $67.5 \%$. Terdapat 5 mahasiswi gizi dan 8 mahasiswi hukum yang memiliki status gizi kurang, serta terdapat 7 mahasiswi gizi dan 6 mahasiswi hukum yang memiliki status gizi lebih. Meskipun dari kedua kelompok baik mahasiswi gizi maupun hukum memiliki tingkat pengetahuan gizi yang berbeda dan memiliki asupan energi kurang, namun sebagian besar dari kedua kelompok responden memiliki status gizi yang baik. Hal ini tidak sejalan dengan penelitian sebelumnya yang menyebutkan bahwa perilaku makan seseorang akan mempengaruhi status gizinya. ${ }^{4}$ Sebagai seseorang yang beranjak dewasa tentunya sangat memperhatikan penampilan fisiknya terutama bagi kaum perempuan. Mereka akan berupaya menjaga berat badan ideal, meskipun belum menjalankan perilaku makan dengan baik.

\section{SIMPULAN}


Terdapat perbedaan yang bermakna pada pengetahuan gizi antara kelompok subjek mahasiswi gizi dan non gizi $(p=0.000)$ dengan rerata \pm standar deviasi skor pengetahuan gizi pada mahasiswi gizi sebesar $91.375 \pm 7.069$, sedangkan pada mahasiswi non gizi sebesar $66.625 \pm 14.909$. Namun tidak terdapat perbedaan yang bermakna pada body image $(p=0.155)$, asupan energi $(p=0.162)$ dan status gizi $(p=0.340)$ antara kelompok subjek mahasiswi gizi dan non gizi. Sebagian besar subjek memiliki body image positif, belum memiliki asupan energi yang cukup dan ratarata memiliki status gizi yang normal.

\section{SARAN}

Dilakukan penelitian dengan mahasiswi seluruh angkatan sehingga dapat diketahui apakah ada perbedaan dari masing-masing angkatan yang ada.

\section{DAFTAR PUSTAKA}

1. Saptawati Badosono. 2009. Masalah Gizi di Indonesia. Departemen Ilmu Gizi Fakultas Kedokteran Universitas Indonesia. Majalah Kedokteran Indonesia. Vol. 59, No.1. p.491-494.

2. Badan Perencanaan Pembangunan Nasional (Bappenas). 2011. Rencana Aksi Nasional Pangan dan Gizi 2011-2015. Jakarta: Kementerian Perencanaan Pembangunan Nasional. p.26,33.

3. Riset Kesehatan Dasar (RISKESDAS) Tahun 2013. 2013. Jakarta: Badan Penelitian dan Pengembangan Kesehatan Kementrian Kesehatan RI. p.223-230.

4. Achmad Djaeni Soediaoetama. 2008. Ilmu Gizi Untuk Mahasiswa Dan Profesi Jilid I. Jakarta: Penerbit Dian Rakyat.

5. Merinta Sada, Veni Hadju, Djunaedi M.Dachlan. 2012. Hubungan Body Image, Pengetahuan Gizi Seimbang, Dan Aktivitas Fisik Terhadap Status Gizi Mahasiswa Politeknik Kesehatan Jayapura [skripsi]. Program Studi Ilmu Gizi Fakultas Kesehatan Masyarakat, Universitas Hasanuddin, Makassar. Media Gizi Masyarakat Indonesia. Vol.2, No.1.p. 4448.

6. Rizki Putri Anjani. 2013. Perbedaan Pengetahuan Gizi, Sikap Dan Asupan Zat Gizi Pada Dewasa Awal [skripsi]. Program Studi Ilmu Gizi Fakultas Kedokteran Universitas Diponegoro.

7. Pramadavita Andini. Hubungan Pengetahuan Gizi dengan Asupan Zat Gizi Makro dan Mikro Mahasiswa Ilmu Gizi Fakultas Kedokteran Universitas Diponegoro [skripsi]. 2010. Program Studi Ilmu Gizi Fakultas Kedokteran Universitas Diponegoro.

8. Christan C. Maharibe, Shirley E.S.Kawengian, Alexander S. L. Bolang. 2013. Hubungan Pengetahuan Gizi Seimbang Dengan Praktik Gizi Seimbang Mahasiswa Program Studi Pendidikan
Dokter Angkatan 2013 Fakultas Kedokteran Universitas Sam Ratulangi [skripsi]. Manado.

9. Sari C. E. Paramitha. 2007. Hubungan Antara Pengetahuan Gizi, Body Image, Perilaku Kontrol Berat Badan Dengan Kejadian Kurang Gizi Pada Remaja Putri di SMU Negeri 1 Semarang [skripsi]. Universitas Diponegoro.

10. Nanik Setijowati, Laksmi Karunia T, Nidya Magdalena. Hubungan Antara Body Image Dengan Status Gizi Remaja Putri Di SMA Katolik Frateran Malang [skripsi]. Program Studi Ilmu Gizi Fakultas Kedokteran Universitas Brawijaya.

11. Kusumajaya.Ngurah.A.A. 2007. Persepsi Remaja Terhadap Body Image (Citra Tubuh) Kaitannya dengan Pola Konsumsi Makan dan Status Gizi. Jurnal Skala Husada.

12. Devi Bestiana. 2012. Citra Dan Konsep Tubuh Ideal Mahasiswi FISIP Universitas Airlangga Surabaya [skripsi]. Vol.1, No.1.

13. Tejuyuwono T.A.A. 2011. Persepsi Mahasiswa Program Studi Ilmu Gizi Kesehatan Terhadap Citra Tubuh Ahli Gizi. Jurnal Klinik Indonesia. 8 (1).

14. Nurmalia Syahriri, Abdul Razak Thaha, Nurhaedar Jafar. 2013. Pengetahuan Gizi, Body Image, Dan Status Gizi Remaja Islam Athirah Kota Makassar Tahun 2013 [skripsi]. Program Studi Ilmu Gizi Fakultas Kesehatan Masyarakat Universitas Hasanuddin.

15. Irasmi. 2012. Perilaku Mahasiswa Dalam Memilih Jenis Makanan dan Minuman di Makassar Town Square [skripsi]. Fakultas Ilmu Sosial dan Ilmu Politik Universitas Hasanuddin.

16. Kimberly M. Nutrition In The Adult Years. 2004. In: Mahan K, Escott-Stump S. Krause's food, Nutrition And Diet Therapy. $11^{\text {th }}$ edition. Philadelphia: Saunders.

17. Soetjiningsih. 2004. Buku Ajar Tumbuh Kembang Remaja dan Permasalahannya. p.47-52.

18. Ali Khomsan. 2004. Teknik Pengukuran Pengetahuan Gizi. Bogor: IPB.

19. Cooper PJ, Taylor MJ, Cooper Z, Fairburn CG. 1987. The Development And Validation Of The Body Shape Questionnaire. Int Eat Disord. 6(4):485-94.

20. Dewi Diana Septiani, Briawan D. 2010. Penggunaan Metode Body Shape Questionaire (BSQ) Dan Figure Rating Scale (FRS) Untuk Pengukuran Persepsi Tubuh Remaja Perempuan. Jurnal Gizi Indon. 33 (1): 29-36.

21. A. Wawan, Dewi M. . 2010. Teori Dan Pengukuran Pengetahuan, Sikap, dan Perilaku Manusia. Yogyakarta. Nuha Medika. p.12-14, 48.

22. Ruka Samakaki, Kenji Toyama, Rie Amamoto, Chuan-Jun Liu, Naotaka Shinfuku. 2005. Nutritional Knowledge, Food Habits and Health Attitude of Chinese University Students- A Cross Sectional Study. Nutrition Journal.

23. Ansari W.E., Clausen S.V., Mabhala A., C. Stock. 2010. How do I look? Body Image Perceptions Among University Students From England And 
Denmark. Int. J. Environ. Res Public Health. p. 7: 583-595.

24. Irwanto. 2002. Psikologi Umum. Jakarta: PT Prenhallindo, Jakarta. p.71-85.

25. Kakekshita. S. Idalina, Almeida. S. Sebastiao. 2008. The relationship between body mass index and body image in brazilian adults. Journal Psychology \& Neuroscience. 1(2): 103-7.

26. Fitria Meriyanti. 2013. Pengaruh Pengetahuan Gizi, Persepsi Body Image, Kebiasaan Makan dan Aktivitas Fisik terhadap Status Gizi Mahasiswi Gizi dan Non Gizi IPB [skripsi]. Institut Pertanian Bogor.

27. Dedeh Kurniasih, Hilman Hilmansyah, Marfuah Panji Astuti, Seful Imam. 2010. Sehat dan Bugar Berkat Gizi Seimbang. Jakarta: Kompas Gramedia. p. 93-94.

28. Gibson S. Rosalind. 2005. Principles of Nutritional Assessment. New York: Oxford University Press.

29. Soekirman. 2006. Hidup Sehat Gizi Seimbang Dalam Siklus Kehidupan Manusia. PT. Primamedia Pustaka: Jakarta.

30. Soekidjo Notoatmodjo. 2003. Pendidikan dan Ilmu Perilaku Kesehatan. edisi 1. Jakarta: Rineka Cipta.

31. N.H.Abdull Hakim, N.D.Muniandy, Ajau Danish. Nutritional Status and Eating Practid 2012. Universitiy among University Students in Selected Universities in Selangor, Malaysia. Asian Journal of Clinical Nutrition. 4 (3): 77-87.

32.Rubina A. Sajnawi, Sana Shoukat, Rushna Raza, Muhammad Muhyeuddin Shiekh, Quratulain Rashid. 2009. Knowledge and Practice of Healthy Lifestyle and Dietary Habits in Medical and Non-Medical Students of Karachi, Pakistan. Department of Community Health Sciences. Vol. 59. 